\title{
The cytotoxic and growth inhibitory effects of palladium(II) complexes on MDA-MB-435 cells
}

Nathália Cristina Campanella ${ }^{1}$, Mariana da Silva Demartini ${ }^{2}$, Claudia Torres ${ }^{2}$, Eduardo Tonon de Almeida ${ }^{2}$ and Cibele Marli Cação Paiva Gouvêa ${ }^{1}$

${ }^{1}$ Laboratório de Cultura de Células, Instituto de Ciências da Natureza, Universidade Federal de Alfenas, Alfenas, MG, Brazil.

${ }^{2}$ Laboratório Interdisciplinar de Química, Instituto de Química, Universidade Federal de Alfenas, Alfenas, MG, Brazil.

\begin{abstract}
The antitumorigenic potential of two palladium(II) complexes, $\left[\mathrm{Pd}\left(\mathrm{ca}_{2}-\mathrm{o}-\mathrm{phen}\right) \mathrm{Cl}_{2}\right]-\mathrm{C} 1$ and $[\mathrm{Pd}(\mathrm{dmba})(\mathrm{dppp}) \mathrm{Cl}]-$ C2, was evaluated, using MDA-MB-435 cells, a human breast adenocarcinoma cell-line that does not express the estrogen receptor $\alpha$ (ER-). Growth inhibition and induced alterations in cell-morphology were analyzed. The sulforhodamine $B$ test showed that, compared to control cells, both $C 1$ and $C 2$ significantly inhibited $(p<0.5)$ cell growth. The maximum effect with both was achieved with $1 \mu \mathrm{M}$ complexes, after $24 \mathrm{~h}$ of treatment. No further cell-growth inhibition was achieved by increasing concentration or incubation time. Cell morphology was analyzed after staining with hematoxylin-eosin (HE). The morphological changes noted in the treated cells were cell rounding-up, shrinkage, nuclear condensation and reduction of cell length $(p<0.05)$, thereby indicating that both $\mathrm{C} 1$ and $\mathrm{C} 2$ are cytotoxic to breast adenocarcinoma cells. All together, there was every indication that, by decreasing cell growth and inducing morphological changes, the tested complexes are cytotoxic, hence their potentiality as promising candidates for antineoplastic drug development.
\end{abstract}

Key words: adenocarcinoma cells, antitumor, breast cancer, chemotherapy, coordination complexes.

Received: June 6, 2011; Accepted: December 2, 2011.

\section{Introduction}

Globally, 12.7 million new cases of cancer and 7.6 million deaths were estimated to have occurred in 2008. Worldwide, the second most commonly diagnosed type is breast cancer, with an estimated 1.4 million new cases (10.9\% of all cancers diagnosed) and 458,000 deaths in 2008 (Jemal et al., 2010). For 2010, 49,000 new cases of breast cancer were expected for Brazil alone and 1.5 million worldwide, with the highest mortality rates in low- and middle-income countries (Anderson, 2010; Brazil, 2011).

Through breast carcinoma development being multifactorial in a multistep mutational process, cells acquire a set of genetic lesions, leading to a cancerous state with the subsequent forming of phenotypically different tumors. Phenotypic changes during breast-cancer progression reflect aberrant gene expression and pathways supporting deregulated growth. The various forms of expression of estrogen receptor (ER), progesterone receptor, and human epithelial growth factor receptor-2, are important molecu-

Send correspondence to Cibele Marli Cação Paiva Gouvêa. Laboratório de Cultura de Células, Universidade Federal de Alfenas, Rua Gabriel Monteiro da Silva 700, 37130-000 Alfenas, MG, Brazil. E-mail: cibelegouvea@ hotmail.com. lar markers used in clinical practice for disease diagnosis, prognosis and therapy. ER expression is one of the most important markers for the selection of adequate breast cancer therapy (Giacinti et al., 2006; Oldenhuis et al., 2008; Sahab et al., 2011). Around $60 \%$ of all breast cancers diagnosed are ER positive (ER+), a noninvasive differentiated breast cancer which responds to antiestrogen therapy. Nevertheless, some breast cancer cells, through losing the ability to express ER, give rise to a therapy-resistant cancer. ER negative (ER-) breast cancers are a highly invasive, dedifferentiated form of breast carcinoma, which have been associated with focal myoepithelial disruption, a lack of expression of tumor suppressors, and a higher rate of cell proliferation, itself increasing metastatic potential, thereby posing a challenge to treatment (Sahab et al., 2011).

Despite favorable prognosis if early detected, and recent progress in drug therapy, there are no effective drugs for treating and curing most types of breast cancers, especially metastatic ER-tumors (Oldenhuis et al., 2008; Brough et al., 2011). Serious side effects have become obstacles in treatment when using current compounds with anticancer activity (Rybak et al., 2009), whereby the necessary search for new potential antitumor substances to im- 
prove treatment efficacy with smaller doses and less toxic drugs. The development of drugs that selectively eliminate cancer cells without harming normal ones, also remains a considerable challenge (Brough et al., 2011).

The first step in the search for new anticancer drugs is in vitro screening to detect the cytotoxic and cytostatic effects of a compound. Collectively, cytotoxicity comprises a set of biochemical and genetic alterations that disrupt cell homeostasis, and it could be estimated by enzyme release, cell viability, survival and death assays, among others ( $\mathrm{Su}-$ mantran, 2011).

A cytotoxic compound induces short-term loss of cell viability either by triggering cell-death or decreasing cellsurvival. In contrast, a cytostatic elicits long-term cell survival or cell proliferation without affecting eventual, viable cell-number (Sumantran, 2011). The first and most readily observed effects, following cell exposure to toxicants, are morphological alterations in the cell-layer and/or cell-shape in monolayer cultures. Another indicator of cytoxicity is altered cell growth (Ekwall et al., 1990).

Most synthetic metal complexes used as antitumor chemotherapeutic compounds are structural analogs of cisplatin. Recently, the palladium (II) complexes were included among the newly introduced structural types of metallic complexes, designed for increased antitumor efficiency and decreased toxicity to normal cells (Caires et al., 1999; Kontek et al., 2011). The first of these had little or no application as antitumor compounds, due to poor stability and rapid hydrolysis in biological environments. However, the use of chelating ligands in their synthesis was opportune in improving their stability, which was further improved by the generation of cyclopalladated compounds (Caires, 2007).

Previous studies by our group have shown that the palladium(II) complexes are cytotoxic to tumor cells (Caires et al., 1999; Rocha et al., 2007), although there are no available data on their toxicity to ER- breast tumor cells.

The aim of the present study was to evaluate the cytotoxic activity of two synthesized palladium(II) complexes in the human breast adenocarcinoma cell line, MDA-MB-435 (ER-), a highly invasive, estrogen independent and dedifferentiated breast carcinoma cell line, by analyzing their effect on cell growth and morphology.

\section{Materials and Methods}

\section{Reagents}

All reagents, solvents and ligands $(\mathrm{dmba}=$ dimethylbenzylamine and dppp = (diphenylphosphine)propane) were purchased from Sigma-Aldrich, St Louis, USA (ACS quality) and employed without further purification.

\section{Ligand synthesis}

The iminic ligand or Schiff's base $\left(\mathrm{ca}_{2}-\mathrm{o}-\mathrm{phen}=\right.$ bis(cinnamaldehyde)-o-phenylenediimine) was synthe- sized as follows: A solution of trans-cinnamaldehyde $1.14 \mathrm{~g}(8.6 \mathrm{mmol})$ in ethanol $(2 \mathrm{~mL})$ was added dropwise to an ethanolic solution $(20 \mathrm{~mL})$ of $o$-phenylenediamine $0.47 \mathrm{~g}(4.3 \mathrm{mmol})$. The reaction mixture was stirred at room temperature for $3 \mathrm{~h}$. After cooling for $24 \mathrm{~h}$, a white solid took form. The pellet was filtered off, washed with ethanol, water and ethyl ether, and finally vacuum-dried.

\section{Palladium(II) complex synthesis}

$\left[\mathrm{Pd}\left(\mathrm{Ca}_{2}-\mathrm{o}-\right.\right.$ phen $\left.) \mathrm{Cl}_{2}\right](\mathrm{C} 1)$

The complex $\left[\mathrm{Pd}\left(\mathrm{ca}_{2}-o\right.\right.$-phen $\left.) \mathrm{Cl}_{2}\right](\mathrm{C} 1)$ was synthesized as follows: A solution of imine $\mathrm{ca}_{2}-o$-phen $0.15 \mathrm{~g}$ $(1.16 \mathrm{mmol})$ in methanol $(20 \mathrm{~mL})$ was slowly added dropwise to a solution containing palladium(II) chloride $0.411 \mathrm{~g}(2.32 \mathrm{mmol})$ and lithium chloride $0.197 \mathrm{~g}$ $(4.46 \mathrm{mmol})$ dissolved in methanol $(50 \mathrm{~mL})$. The resulting solution was stirred at room temperature for $8 \mathrm{~h}$. The pale yellow pellet thus formed was filtered off and washed with ethanol, water and ethyl ether, and then vacuum-dried.

\section{$[\mathrm{Pd}(\mathrm{dmba})(\mathrm{dppp}) \mathrm{Cl}](\mathrm{C} 2)$}

Synthesis of $[\mathrm{Pd}(\mathrm{dmba})(\mathrm{dppp}) \mathrm{Cl}](\mathrm{C} 2)$ has already been described (Caires et al., 1999). Planar molecular geometry of the two palladium(II) complexes synthesized is shown in Figure 1. Both were dissolved in DMSO $\left(1 \mathrm{mg} \cdot \mathrm{mL}^{-1}\right)$ and diluted with distilled water to obtain the desired concentration.

\section{Cell line culture}

Human breast adenocarcinoma MDA-MB-435 cells were purchased from the Rio de Janeiro Cell Bank (CR 117), and cultured in RPMI 1640, supplemented with $20 \%$

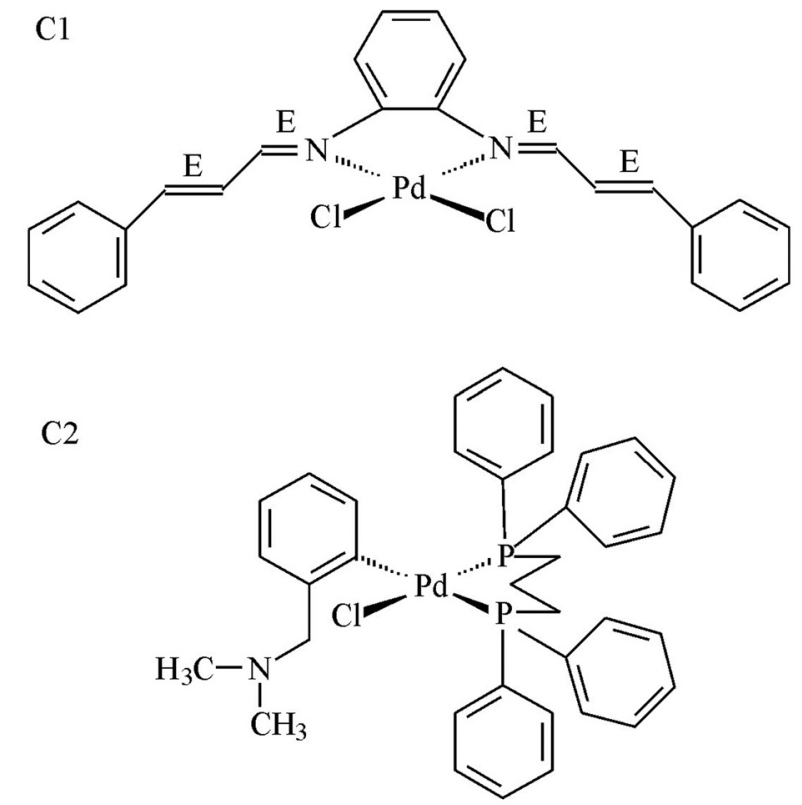

Figure 1 - Structures of palladium(II) complexes. C1, [Pd( $\mathrm{ca}_{2}-O-$ phen $\left.) \mathrm{Cl}_{2}\right] ; \mathbf{C 2}$, [Pd(dmba)(dppp)Cl]. 
(v/v) inactivated fetal bovine serum, $100 \mathrm{U} \cdot \mathrm{mL}^{-1}$ penicillin and $100 \mu \mathrm{g} \cdot \mathrm{mL}^{-1}$ streptomycin. Cells were maintained in a humidified atmosphere with $5 \% \mathrm{CO}_{2}$ at $37{ }^{\circ} \mathrm{C}$. Before beginning each experiment, cell viability was assessed by the trypan blue-dye exclusion method and $2.10^{4}$ viable cells. $\mathrm{mL}^{-1}$ were used in all experiments.

\section{Cell growth analysis}

The effect of $\mathrm{C} 1$ and $\mathrm{C} 2$ complexes on cell growth was determined by the sulforhodamine B (SRB) colorimetric assay (Vichai and Kirtikara, 2006). Briefly, cells were seeded onto 96-well plates, and then left for $24 \mathrm{~h}$ to reach exponential growth. The medium was replaced, whereupon the cells were treated with vehicle (negative control), $5.0 \mu \mathrm{M}$ cisplatin (positive control), or various concentrations of both complexes $(0.1,0.5,1.0,5.0$ and $10.0 \mu \mathrm{M})$. Cells were then incubated for 24 and $48 \mathrm{~h}$ and fixed with $10 \%$ trichloroacetic acid (w/v) for $30 \mathrm{~min}$ at $4{ }^{\circ} \mathrm{C}$. After careful removal of the plate content, each well was washed with distilled water. The plate was then dried for $24 \mathrm{~h}$ and stained with $0.4 \% \mathrm{SRB}(\mathrm{w} / \mathrm{v})$ in $1 \%$ acetic acid (v/v) for $30 \mathrm{~min}$, after which, excess SRB was removed, and the wells washed 4 times with $1 \%$ acetic acid $(\mathrm{v} / \mathrm{v})$. The bound SRB was dissolved by adding $100 \mu \mathrm{L}$ of $10 \mu \mathrm{M}$ Tris $\mathrm{pH} 10.5$ for $10 \mathrm{~min}$ and absorbance read at $510 \mathrm{~nm}$.

\section{Morphological analysis}

Morphological analysis, with modifications, was as described by Pedro et al. (2006). In order to reach exponential growth, cells were cultured on coverslips for $24 \mathrm{~h}$ to achieve the exponential growth, whereupon the medium was replaced, and the cells treated with various concentrations of the $\mathrm{C} 1$ and $\mathrm{C} 2$ complexes $(0.1,0.5,1.0$ and $5.0 \mu \mathrm{M})$ for $24 \mathrm{~h}$. Cells treated with the vehicle were the negative control, and with $5.0 \mu \mathrm{M}$ cisplatin, the positive. After treatment, cells were fixed with $70 \%$ acetone and stained with hematoxylin-eosin. Slides were mounted in Entellan and observed by light microscopy. Cell digital images were acquired with an Olympus BX52 microscope and Motic Images Plus 2.0 software. Fifteen aleatory fields were analyzed per treatment, to describe cell morphology. In each treatment, 30 cells (two per field) were measured with Motic Images Plus 2.0 software, in order to determine cell length.

\section{Statistical analysis}

Obtained data were compared by one-way analysis of variance (ANOVA), followed by the Tukey test, when $\mathrm{p}<0.05$. Data are shown as the mean \pm SEM of three independent experiments.

\section{Results and Discussion}

After completing synthesis, the palladium(II) complexes were investigated for in vitro antitumor activity when using the hormone-insensitive human breast-cancer cell line, MDA-MB-435. This cell-line does not express $\mathrm{ER} \alpha$, and has been used as the model in metastatic breastcancer studies. Even though some previously synthesized palladium(II) complexes have proved to be cytotoxic to tumor cells, their effect on breast-cancer cells remains unknown. It is also important to evaluate the cytotoxicity of newly synthesized complexes with increased stability, the case of $\mathrm{C} 1$.

We evaluated the cytotoxicity of $\mathrm{C} 1$ and $\mathrm{C} 2$ complexes using the SRB assay (Figure 2). SRB, in moderated acid conditions, binds stoichiometrically to basic protein aminoacids. The OD observed is well correlated to cell number, thus being an indicator of the cell growth (Vichai and Kirtikara, 2006). The results depicted in Figure 2 show that both complexes hindered cell growth and the maximum effect was obtained with $1 \mu \mathrm{M} \mathrm{C} 1$ and $\mathrm{C} 2$ after $24 \mathrm{~h}$ incubation. No further significant $(\mathrm{p}>0.05)$ hinderance was achieved by increasing $\mathrm{C} 1$ and $\mathrm{C} 2$ concentration or incubation time. Thus, it is possible to sustain the positive cytotoxic role of these synthesized complexes in the inhibition of MDA-MB-435 cell growth and spread.

$\mathrm{C} 1, \mathrm{C} 2$ and cisplatin treatment induced alterations in cell morphology, such as nuclear condensation, cell rounding-up and shrinkage indicating cytoskeleton disruption (Figure 3). Untreated control cells presented irregular spindle-shaped morphology, were homogeneously stained, with the cytoplasm less stained than the nucleus and the nucleolus remained plainly visible. On the other hand, when exposed to $\mathrm{C} 1$ and $\mathrm{C} 2$ complexes, cells became rounded

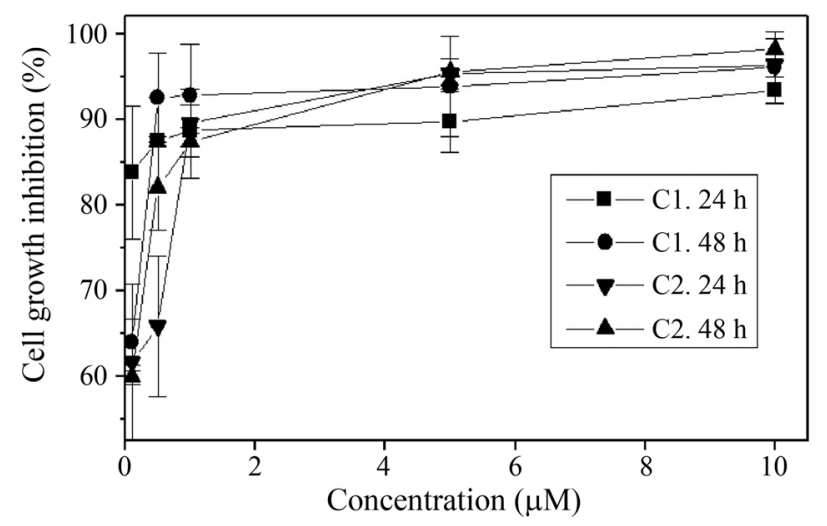

Figure 2 - Cell growth inhibition (\%) after treatment with different palladium(II) complex ( $\mathrm{C} 1$ and $\mathrm{C} 2$ ) concentrations for 24 and $48 \mathrm{~h}$, estimated by the sulforhodamine $\mathrm{B}$ assay. $\mathbf{C 1},\left[\mathrm{Pd}\left(\mathrm{ca}_{2}-o-\mathrm{phen}\right) \mathrm{Cl}_{2}\right] ; \mathbf{C 2}$, $[\mathrm{Pd}(\mathrm{dmba})(\mathrm{dppp}) \mathrm{Cl}]$. Growth inhibition was calculated relative to the negative control. The results are expressed as mean \pm SEM of three independent experiments. Note that the results were similar in both cases. 
and individually separated, with cell shrinkage, nuclear condensation and wrinkled cytoplasmic membranes.
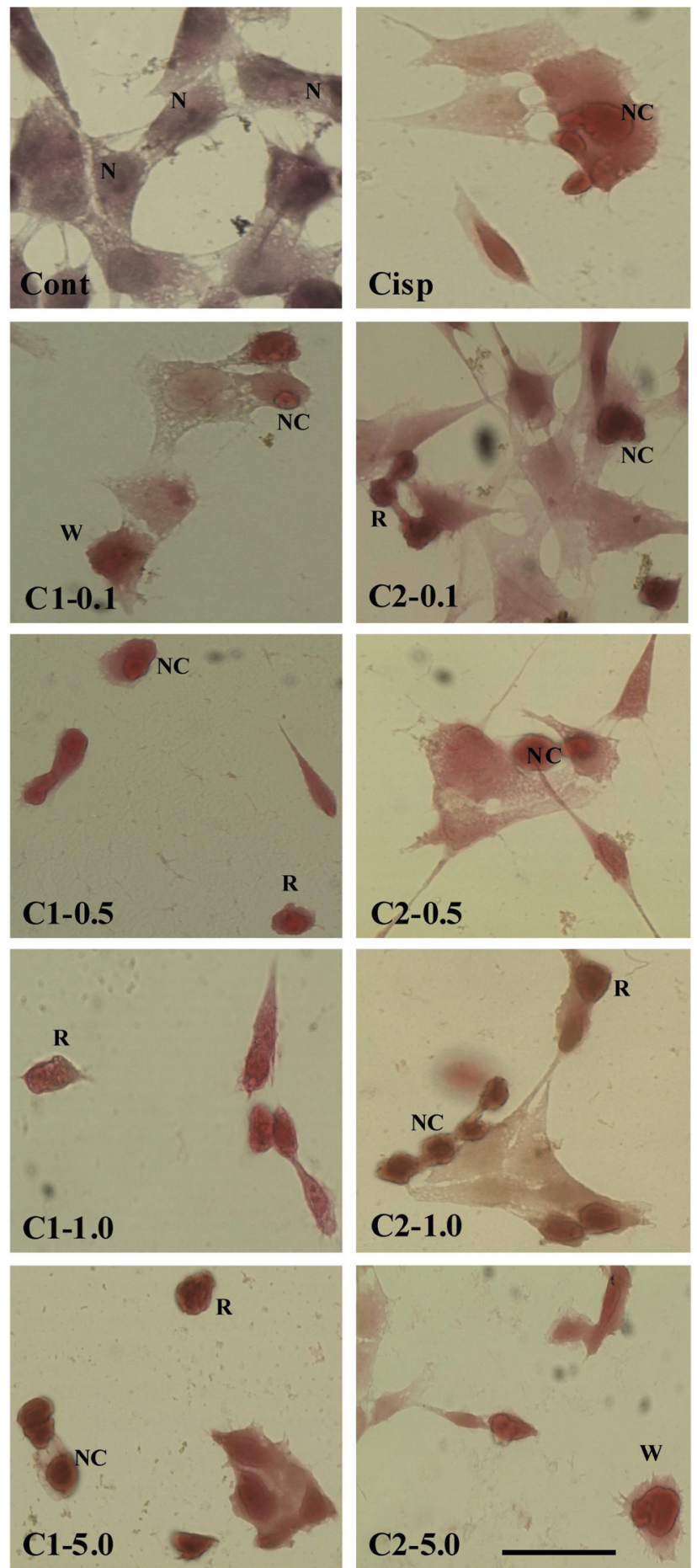

Figure 3 - Morphology of MDA-MB-435 cells stained with hematoxylin and eosin, after $24 \mathrm{~h}$ incubation. Cont, control cells; Cisp, cells treated with $5 \mu \mathrm{M}$ cisplatin; $\mathbf{C 1}$, cells treated with $\left[\mathrm{Pd}\left(\mathrm{ca}_{2}-o-\right.\right.$ phen $\left.) \mathrm{Cl}_{2}\right]$; $\mathbf{C 2}$, cells treated with $[\mathrm{Pd}(\mathrm{dmba})(\mathrm{dppp}) \mathrm{Cl}]$. Palladium(II) complexes were added to the cell culture at $0.1,0.5,1.0$ and $5.0 \mu \mathrm{M}$. All the pictures are typical of three independent experiments, each carried out under identical conditions. Bar $=20 \mu \mathrm{m}$. N - nucleolus; $\mathrm{R}$ - rounding; $\mathrm{NC}$ - nuclear condensation; $\mathrm{W}$ - wrinkled cytoplasmic membranes.
When undergoing $\mathrm{C} 1$ and $\mathrm{C} 2$ treatment for 24 and $48 \mathrm{~h}$, there was a significant $(\mathrm{p}<0.01)$ decrease in celllength in comparison to control cells. The complex effect proving to be similar to the cisplatin (Figure 4), even at lower concentrations. All told, these morphological alterations indicated $\mathrm{C} 1$ and $\mathrm{C} 2$ cytotoxicity.

The results herein corroborate the findings of Barbosa et al. (2006) showing palladium(II) complex cytotoxicity to cultured cells, with a decrease in cell number, chromatin condensation, and consequent viability reduction.

Caires et al. (1999), when studying C6, HeLa and Hep-2 cell lines, observed cell-growth inhibition upon palladium(II) complex treatment, with concentrations higher than those obtained in the present work. Here, the maximum effect on cell-growth inhibition was achieved with $0.1 \mu \mathrm{M} \mathrm{C} 1$ and $\mathrm{C} 2$ complex treatments.

It has been demonstrated that palladium (II) complexes can bind to DNA in both the coordination and intercalative modes, thereby forming the DNA adducts involved in cytotoxic specificity and significant cancer-cell inhibitory activities (Gao et al. 2010, 2011). In the present work, the cytotoxic effect of palladium(II) complexes, possibly due to complex-DNA interaction, was clearly shown.

In conclusion, the tested $\mathrm{C} 1$ and $\mathrm{C} 2$ palladium(II) complexes showed growth inhibition activity and induced alterations in cell morphology, both compatible with cytotoxicity against human breast adenocarcinoma MDA-MB-435 cells. The cytotoxic effect is an indicative of the compound antitumor activity as the majority of clinical used antitumor drugs show cytotoxic activity (Le Tourneau et al., 2010). This is the first report on the C1 and $\mathrm{C} 2$ complexes activity against breast cancer cells and they seem to be good candidates for antineoplastic drug development.

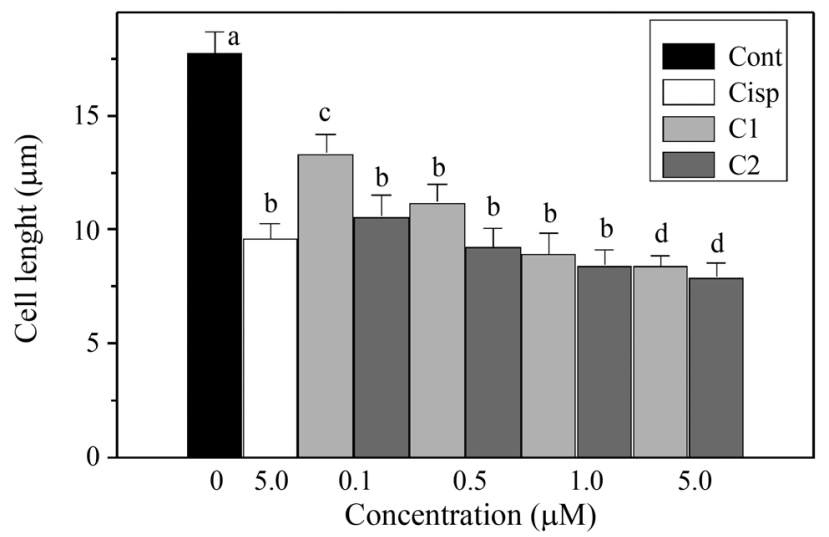

Figure 4 - MDA-MB-435 cell length $(\mu \mathrm{m})$ after $24 \mathrm{~h}$ incubation. Cont, control cells; Cisp, cells treated with $5 \mu \mathrm{M}$ cisplatin; $\mathbf{C 1}$, cells treated with $\left[\mathrm{Pd}\left(\mathrm{ca}_{2}-\mathrm{O}\right.\right.$-phen $\left.) \mathrm{Cl}_{2}\right] ; \mathbf{C 2}$, cells treated with $[\mathrm{Pd}(\mathrm{dmba})(\mathrm{dppp}) \mathrm{Cl}]$. Note cell-length reduction after treatment, in comparison to control cells, thereby indicating $\mathrm{Pd}(\mathrm{II})$ complex cytotoxicity. Results are expressed as mean \pm SEM of three independent experiments. Different letters indicate significant differences $(p<0.01)$ by the Tukey test. 


\section{Acknowledgments}

Financial assistance from CNPq (grants 477264/2008-5 and 14/2008) and FAPEMIG (grants APQ-1305/06, APQ-0446-5.02/07 and APQ-01059/09), and fellowships from CNPq (ETA) and PET-MEC-SESU (CMCPG), are gratefully acknowledged.

\section{References}

Anderson BO (2010) The breast health global initiative (BHGI): Why it matters to all of us. Oncology 24:1-10.

Barbosa CM, Oliveira CR, Nascimento FD, Smith MC, Fausto DM, Soufen MA, Sena E, Araújo RC, Tersariol IL, Bincoletto C, et al. (2006) Biphosphinic palladacycle complex mediates lysosomal-membrane permeabilization and cell death in K562 leukaemia cells. Eur J Pharmacol 542:37-47.

Brough R, Frankum JR, Costa-Cabral S, Lord CJ and Ashworth A (2011) Searching for synthetic lethality in cancer. Curr Opin Genet Dev 21:31-41.

Caires AC (2007) Recent advances involving palladium (II) complexes for cancer. Anticancer Agents Med Chem 7:484-491.

Caires ACF, Almeida ET, Mauro AE, Hemerly JP and Valentini SR (1999) Síntese e atividade citotóxica de alguns azidociclopaladados estabilizados com ligantes bifosfínicos. Quim Nova 22:329-333.

Ekwall B, Silano V, Paganuzzi-Stammati A and Zucco F (1990) Toxicity tests with mammalian cell cultures. In: Bourdeau P, Somers E, Richardson GM and Hickman JR (eds) ShortTerm Toxicity Tests for Non-Genotoxic Effects. John Wiley \& Sons, Inc., New York, pp 75-97.

Gao EJ, Wang L, Zhu MC, Liu L and Zhang WZ (2010) Synthesis, characterization, interaction with DNA and cytotoxicity in vitro of the complexes $\left[\mathrm{M}(\mathrm{dmphen})\left(\mathrm{CO}_{3}\right)\right] \cdot \mathrm{H}_{2} \mathrm{O}[\mathrm{M}=$ Pt(II), Pd(II)]. Eur J Med Chem 45:311-316.

Gao E, Liu L, Zhu M, Huang Y, Guan F, Gao X, Zhang M, Wang L, Zhang W and Sun Y (2011) Synthesis, characterization, interaction with DNA, and cytotoxic effect in vitro of new mono- and dinuclear Pd(II) and Pt(II) complexes with ben$\mathrm{zo}[\mathrm{d}]$ thiazol-2-amine as the primary ligand. Inorg Chem 50:4732-4741.

Giacinti L, Claudio PP, Lopez M and Giordano A (2006) Epigenetic information and estrogen receptor alpha expression in breast cancer. Oncologist 11:1-8.
Jemal A, Center MM, DeSantis C and Ward EM (2010) Global patterns of cancer incidence and mortality rates and trends. Cancer Epidemiol Biomarkers Prev 19:1893-1907.

Kontek R, Matawska-Wasowska K, Kalinowska-Lis U, Kontek B and Ochocki J (2011) Evaluation of cytotoxicity of new trans-palladium(II) complex in human cells in vitro. Acta Pol Pharm 68:127-136.

Le Tourneau C, Diéras V, Tresca P, Cacheux W and Paoletti X (2010) Current challenges for the early clinical development of anticancer drugs in the era of molecularly targeted agents. Target Oncol 5:65-72.

Oldenhuis CN, Oosting SF, Gietema JA and de Vries EG (2008) Prognostic versus predictive value of biomarkers in oncology. Eur J Cancer 44:946-953.

Pedro M, Lourenço CF, Cidade H, Kijjoa A, Pinto M and Nascimento MS (2006) Effects of natural prenylated flavones in the phenotypical ER (+) MCF-7 and ER (-) MDA-MB-231 human breast cancer cells. Toxicol Lett 164:24-36.

Rocha MC, Santana AM, Ananias SR, Almeida ET, Mauro AE, Placeres MCP and Carlos IZ (2007) Cytotoxicity and immune response induced by organopalladium(II) compounds in mice bearing Ehrlich ascites tumour. J Braz Chem Soc 18:1473-1480.

Rybak LP, Mukherjea D, Jajoo S and Ramkumar V (2009) Cisplatin ototoxicity and protection: Clinical and experimental studies. Tohoku J Exp Med 219:177-186.

Sahab ZJ, Man YG, Byers SW and Sang QX (2011) Putative biomarkers and targets of estrogen receptor negative human breast cancer. Int J Mol Sci 12:4504-4521

Sumantran VN (2011) Cellular chemosensitivity assays: An overview. In: Cree IA (ed) Cancer Cell Culture: Methods and Protocols (Methods in Molecular Biology 731 Springer Protocols). 2nd edition. Humana Press, New Jersey, pp 219236.

Vichai V and Kirtikara K (2006) Sulforhodamine B colorimetric assay for cytotoxicity screening. Nat Protoc 1:1112-1116.

\section{Internet Resources}

Brazil, Ministério da Saúde, Instituto Nacional do Câncer (2010) Tipos de câncer: Mama, http://www2.inca.gov.br/wps/ wcm/connect/tiposdecancer/site/home/mama (May 2, 2011).

Associate Editor Jeremy A. Squire

License information: This is an open-access article distributed under the terms of the Creative Commons Attribution License, which permits unrestricted use, distribution, and reproduction in any medium, provided the original work is properly cited. 